\title{
関節突起骨折に対する透視下における非開放下整復術の治療経験
}

\author{
酒巻裕之・秋葉正一・関睦弘 \\ 鯨岡裕晃·青木秀史・山口福光*
}

\section{Closed reduction of a mandibular condyle fracture under fluoroscopy}

\author{
Hiroyuki SaKamaki $\cdot$ Masakazu AKIba $\cdot$ Mutsuhiro SeKI \\ Hiroaki KuJiraoKa $\cdot$ Hidefumi AoKI $\cdot$ Fukumitsu YamaguCHI*
}

\begin{abstract}
The basic principles of treatment for fractures are restoration of the original position, anatomical form, and functions of the affected bone; surgical damage should be minimized. A modified surgical method, closed reduction under fluoroscopy, was used to reduce a condylar process fracture. A 15-year-old man presented to our hospital with a fracture of the right condylar process. The maximal interincisal distance of mouth opening was $37 \mathrm{~mm}$. Radiography showed dislocation and anteromedial deviation of the process fragment. Closed reduction was performed applying a blunt-tip trocar for arthroscopic surgery with its outer sheath as an elevator. The elevator was inserted through the skin in front of the fractured process, and the fragment was reduced with manipulation under fluoroscopy. Intermaxillary fixation was maintained for 48 days. The patient's postoperative course was excellent except for slight transient hypoesthesia of the right lower lip. This procedure has the advantages of minimizing the length of the incision, skin scaring, and risk of injury to the facial nerve and parotid gland.
\end{abstract}

Key words: condylar process fracture of the mandible (関節突起骨折), fluoroscopy (X 線透視), closed reduction (非開放下整復術)

\section{緒言}

われわれは，骨折により偏位脱臼した関節突起に対 し，透視下において非開放的に整復する方法を検討し 試みたところ，良好な結果を得た。本法は非観血的整 復術と観血的整復術の中間に位置する処置法として, 適忍を選択すれば有効な手段であると考えたので，そ の概要を報告する。

総合病院国保旭中央病院歯科口腔外科

(主任: 秋葉正一部長)

* 口本大学松戸歯学部第 1 口腔外科学教室

(主任 : 追川哲雄教授)

Department of Dentistry and Oral Surgery, Asahi

General Hospital (Chief: Masakazu Akiba)

* Department of Oral Surgery, Nihon University School of Dentistry at Matsudo (Chief: Prof. Tetsuo Oikawa)

受付口: 平成 7 年 7 月 19 口

\section{症}

患 者: 四歳, 男性.

初診: 1994 年 8 月日日.

主 訴 : 右側顎関節部疼痛.

家族歴・既往歴：特記事項なし.

現病歴 : 1994 年 8 月曰日, 左側煩部を蹴られて受 傷し, その直後より右側顎関節部の疼痛と咬合不全を 白覚した。次第に開口制限も生じてきたため, 近医よ り紹介されて来院した。

現 症 : 顔貌は右側耳前部に軽度のび慢性腫脹を認 め, 下顎は僅かに左側へ偏位し, 口腔内では右側臼歯 部に開咬を認めた。開口時に下顎は右側に偏位し，右 側耳前部に疼痛を伴い，切歯間における最大開口は $37 \mathrm{~mm}$ であった。

$\mathbf{X}$ 線学的所見：右側関節突起下頸部に骨折線を認 め, 関節突起は下顎窩から冕脱し内前方に偏位脱臼し ていた（写真 1 ).

臨床診断 : 右側関節突起頸部偏位脱臼骨折. 


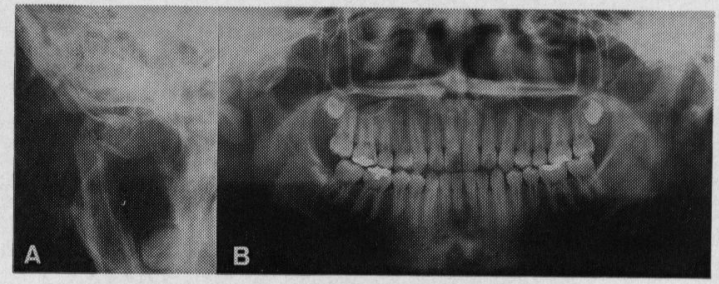

写真 1 初診時 X線写真

$\mathrm{A}:$ 眼窩関節方向

$\mathrm{B}$ : オルソパントモX線写真

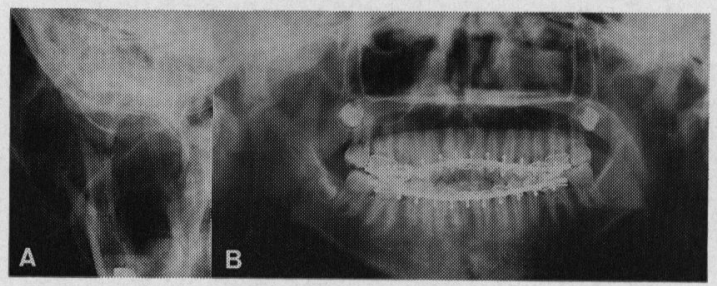

写真 3 術直後X線写真

$\mathrm{A}:$ 眼窩関節方向

$\mathrm{B}$ : オルソパントモ $\mathrm{X}$ 線写真

処置および経過：1994 年 8 月ロ日局所麻酔下で透 視下に関節突起非開放下整復術を施行した。

器具は，関節鏡視下手術に用いる外套管とトロカー ルを使用し，透視装置は (株) 東芝製 Cアーム X 線テ レビシステムを用いた。

患者の体位は側臥位とし，X線の主線方向は米津ら の顎関節腔造影検査法 $\left.{ }^{1}\right)$ と同様に, シュラー法に準じ 上方約 $20^{\circ}$ の経頭蓋側斜方向とした.X 線透視の条件 は, 管電圧 $80 \mathrm{kVp}$, 管電流 $2.0 \mathrm{~mA}$ とし, X線透視像は ビデオレコーダーに記録した。

外套管に装着したトロカールの刺入点は関節結節直 下の皮虐上に設定し，骨折により偏位脱臼した関節突 起頭部のやや前方から関節突起を触知しつつより深部 へと刺入し，下顎骨，トロカールの位置，関節突起の 整復状態を透視下に確認しながら (写真 $2 \mathrm{~A}$ ), 関節突 起を下顎窩に押し戻す方法で施行した。関節突起が下 顎窩内に整復されたことを確認して処置を終了した (写真 2 B).

手術時間は 43 分であり, その間に透視は 7 回行っ たが, 総透視時間は頭部の位置決めの時間を含んで約 60 秒であった，関節突起の整復状態は良好で，関節突 起が再度偏位することもないため, 顎間固定のみ施行 した (写真 3 ). 術直後, 右側下唇に一過性の知覚鈍麻 を認めた。顎間固定は術後 48 口間施行した. その間骨 折片の移動もなく経過は良好であり, 整復後 6 か月経 過時の最大開口は $53 \mathrm{~mm}$ かつ開口時における顎関節 部の疼痛もなく, 咬合状態・顎運動も良好であった (写真 4$)$.

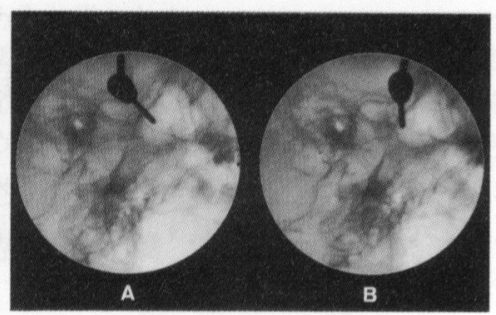

写真 2 術中透視像

A：トロカール刺入時

$B$ : 関節突起整復時

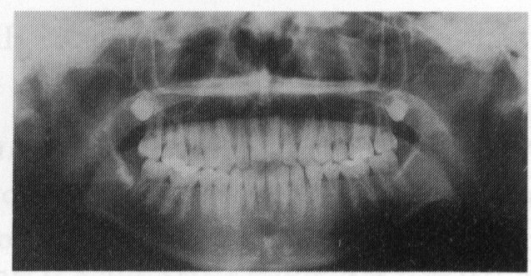

写真 4 整復 6 か月経過時オルソパントモX X線写真

考

察

1. 処置方針について

関節突起骨折は下顎骨骨折の中でも比較的高頻度に 認められるが, 従来よりその治療法については, 観血 的治療を選択するか否かで賛否両論があり，未だに統 一した見解が得られていない. 観血的治療を支持する ものは, 形態を整え顎関節本来の機能を確実に回復さ せようとする積極的な考え方で, 論拠には正当性があ る。しかし, 手術に起因する顔面の洀痕と顔面神経損 傷の危惧, および手術に熟練を要し, また, 繁雑さが あることも事実である.それに対して関節突起骨折の 治療を非観血的に行った場合は, 一般に機能障害は比 較的軽度で, 顎運動時における顎関節部の疼痛もほと んどなく, したがって開口時の下顎の偏位, 異常運動 が許容範囲内にあれば, 形態学的に不正であっても日 常生活の上では特に支障がないことが多い，以上が非 観血的治療を支持する主な根拠と思われる。

関節突起骨折の非観血的処置の適応について Walker は, 「(1) $40 \mathrm{~mm}$ 以上の無痛性開口, (2)あらゆる 方向への良好な顎運動, (3)受傷前の咬合状態が良好で あること, (4)安定した顗関節部の状態，(5)顔貌および 顎が対称性であること」2) と述べている。一方, 久保 らは, 非観血的処置を施行した関節突起骨折症例の骨 折の部位と予後との関倸について, 骨折の部位では関 節頭部, 上頸部, 下頸部, 基底部と骨折部位が低位に なるに従い, また骨折の様態では龟裂, 偏位, 転位, 偏 位脱臼, 転位脱臼と小骨片の位置が大骨片より遊離す るに従い，予後不良例が多くなる傾们にあった $\left.{ }^{3}\right)$ と報 
告している。

われわれは, 関節突起骨折の処置法としては, 白家 矯正 ${ }^{4}$ )を期待して原則として保存的治療法で対処し ているが，一般に予後不良とされている転位脱臼骨折 や基底部の骨折 - 粉砕骨折例については, 観血的処置 が適心 ${ }^{5}$ と考えている.

本症例は, 右側関節突起下頸部の偏位脱臼骨折で偏 位角は約 $90^{\circ}$ であり，下顎骨の左側偏位，右側臼歯部 の開咬を認め, 切歯間における最大開口は $37 \mathrm{~mm} て ゙$, 開口時に下顎は右側に偏位し, 保存的処置では予後不 良になると推測した。ささらに, 日家矯正の可能性をも つ若年者であることを考虑しても，関節突起が脱臼し ているため，良好な状態になることは期待できないと 考えた，そして，骨折の治療原則が正しい解剖学的位 置への整復固定であること ${ }^{6)}$ に鑑み，より侵襲が少な くかつ観血的整復術による皮清瘢痕の残存, 耳下腺, 顔面神経損傷の危険性を回避するために本法を試みた。

2 . 本法の特徴について

われわれの渉猟しえた範囲では, 透視下にトロカー ルを起子として関節突起骨折の整復を施行した報告は 認められなかった。術式は基本的には顎関節鏡視下手 術の外套管穿刺の操作と同様で, それを通法よりやや 前方の位置で施行し, 関節包の外から力を作用させて 整復したものであり, 手術侵襲がきわめて少ないこと が本法の利少である。しかしながら，操作の一部は盲 目的となり手指感覚に頼らざるをえない部分があり， また関節突起が転位脱臼骨折している場合には本法に よる整復が困難であると考えられた。

一般に，骨折 1 ～週後の凝血器質化の時期には, 伦芽組織が定型的な結合組織となり，一伈骨を連繋し て骨折端の大きな移動が抑制される ${ }^{4)}$ ため, 整復時期 に関しては骨折後可及的早期に施行することが朋要と 思われた。

3. 骨折端の固定について

関節突起骨折の場合, 外側翼突筋の衰引力による偏 位が問題になると考える。しかし，本㱑例においては 関節突起の整復状況は良好で, 処置後は骨折端が本来 の位置で论合状態となり, 結果としてその後の関節突 起の外側翼突筋の毫引による偏位は生じなかったため, 顎間固完のみで十分であると推考した。

4. 顎間固定期間について

顎間固定期間は 48 口間を必要とした。これは，当初 骨折部の安静を図る目的で 4 週間の顎間固定を行った
が, 顎間固定解除後に右側臼歯部が僅かに開咬を呈し たので, 顎間固定期間を延長したためである。本症例 の関節突起の整復状態は, X線学的には満足できるも のであったが, 開咬の原因を勘案すると, 骨折端の接 合部に間隙が生じて関節突起の長さが受傷前に比較し て僅かに長くなったためと思われた。この点に関して は, 本法では顎間固定解除の時期は各症例ごとに十分 に検討する必要があるものと推察した。

5 . 術後合併症について

術直後より右側下唇の知覚鈍麻を訴えた。これは， 関節突起内側に走行する下顎神経との位置関係による もの ${ }^{7)}$ で, 内前方に脱臼していた関節突起が下顎神経 に接近していたため, 整復時に下顎神経を機械的に圧 迫したことによるものと推察した。知覚鈍麻は, 処置 後 3 週間経過時には消失し, 以後異常は認めていない.

\section{結語}

骨折により偏位脱臼した関節突起に対し，透視下に 整復する方法を考案し施行した. 本法は非開放下整復 術であるが, 非観血的整復術と観血的整復術との中間 的な処置法として, 適忍症を選択すれば有効な手段で あると考えた。

\section{引用文 献}

1) 米津博文, 関 泰忠, 他：X線テレビシステム を用いる顎関節腔造影検査法について. 日外 誌 33: 937-949 1987.

2) Walker, R.V.: Condylar Fractures Nonsurgical Management-. J Oral Maxillofac Surg. 52: 1185-1188 1994.

3）久保四郎, 村橋 護, 他: 顎関節突起骨折 124 症例に関する臨床的検討, 特にその分類につい て. 日外誌 29: 1794-1805 1983.

4）青木虎吉：骨折の治療. 天児民和監修; 新臨床 整形外科全書, 第 1 巻 A. 第 1 版, 金原出版, 東 京, 1983, 287-341 頁.

5）秋葉正一, 秋葉和実, 他: 顎関節部の観血的治 療について. 日大口腔科学 14: 337-349 1988.

6）大西正俊, 大月佳代子, 他：口内法による下顎 骨関節突起骨折の治療法. 日顎誌 $5: 62-77$ 1993.

7）橘田博純, 林 栄寿, 他：開口時における日本 人下顎神経, 顎動脈, 顎静脈の走行について。 歯科学報 85: 1523-1532 1985. 